\title{
A New Record of Ihlea punctata and Redescription of Salpa fusiformis (Salpida: Salpidae) in Korean Waters
}

\author{
Sunwoo Kim¹, Jung-Hye Won ${ }^{2}$, Jaehyun Lee $^{3}$ and Chang-Bae Kim ${ }^{3, *}$ \\ ${ }^{1}$ Ecocean Co., Ltd., Incheon 406-840, Korea \\ ${ }^{2}$ Seodaemun Museum of Natural History, Seoul 120-113, Korea \\ ${ }^{3}$ Department of Green Life Science, Sangmyung University, Seoul 110-743, Korea
}

\begin{abstract}
Two species in two genera of the family Salpidae were identified in Korean waters: Ihlea punctata (Forskal, 1775) and Salpa fusiformis Cuvier, 1804. I. punctata is a newly reported species in Korean fauna, while $S$. fusiformis is redescribed with unrecorded solitary zooid stage.
\end{abstract}

Keywords: Urochordata, Salpida, Salpidae, Korea, new record

\section{INTRODUCTION}

The salpidae is the one of large family of holoplanktonic tunicates. Forty species in 13 genera have been described in Salpidae (Chihara and Murano, 1997; Esnal and Daponte, 1999). In Korea, three species in three genera, Salpa fusiformis Cuvier, 1804, Iasis zonaria (Pallas, 1774), and Thalia democratica (Forskal, 1775), have been previously reported in the family Salpidae (Rho, 1967; Kim et al., 2010). In this study, Ihlea punctata is newly identified and Salpa fusiformis is redescribed with unrecorded solitary zooid stage in Korea. Four species of four genera in this family are currently recorded from Korean waters.

The specimens were collected with a $417 \mu \mathrm{m}$ mesh IKMT net and preserved in $4 \%$ buffered formalin or $80 \%$ ethyl alcohol. The abbreviation $\mathrm{M}$ indicates the muscle band. Body lengths of the most specimens were measured from the terminus of the oral aperture to the atrial aperture, while aggregate zooids of $S$. fusiformis were measured from the tip of anterior projection to the tip of posterior projection. The materials examined in this study have been deposited in the Seodaemun Museum of Natural History.

\section{SYSTEMATIC ACCOUNTS}

Phylum Chordata Bateson, 1885

Subphylum Tunicata Larmarck, 1816

*To whom correspondence should be addressed
Tel: $82-2-2287-5288$, Fax: $82-2-2287-0098$

E-mail: evodevo@smu.ac.kr
Class Thaliacea Nielsen, 1995

Order Salpida Uljanin, 1884

Family Salpidae Lahille, 1888

Subfamily Salpinae Yount, 1954

$1 *$ Genus Ihlea Metcalf, 1919

${ }^{2 *}$ Ihlea punctata (Forskal, 1775) (Fig. 1A, B)

Salpa punctata Forskal, 1775, p. 114, pl. 35, fig. C (cited from Yount, 1954; Van Soest, 1975).

Ihlea punctata: Fraser, 1947, p. 2; Yount, 1954, p. 295, fig. 10; Van Soest, 1975, p. 119; Madin, 1991, p. 110, fig. T10; Chihara and Murano, 1997, p. 1370; Esnal and Daponte, 1999 , p. 1434, fig. 3.25 .

Material examined. 162 solitary zooids and 215 aggregate zooids, South Sea, $34^{\circ} 05^{\prime} \mathrm{N} 127^{\circ} 96^{\prime} \mathrm{E}, 1$ Apr. 2008; 1 solitary zooid and 9 aggregate zooids, South Sea, $34^{\circ} 05^{\prime} \mathrm{N} 127^{\circ}$ 96'E, 3 Apr. 2008.

Description. Solitary zooid (Fig. 1A): 10-25 mm long, body oval-cylindrical. Test thin, flabby and entirely smooth. Oral aperture and atrial opening terminal. Broad eight muscle continuous around body. MI contiguous with intermediate muscle dorsally. Many muscle contiguous or fused at mid-dorsal region. Oral retractor well developed. Dorsal tubercle elongated, separated from ganglion with short distance. Branchial septum slender, extending from dorsal tubercle to gut. Endostyle thin, extending from behind oral to gut. Gut project with tight circular loop.

Aggregate zooid (Fig. 1B): 5-25 mm long, body elongated oval. Test very flabby. Oral opening anteriodorsal and atrial opeing posteriordorsal. Six muscles asymmetrically arranged. MI to MII separate in right side, while fused in left side.

$1 *$ 고리살파속(신칭), ${ }^{2 *}$ 고리살파(신칭) 

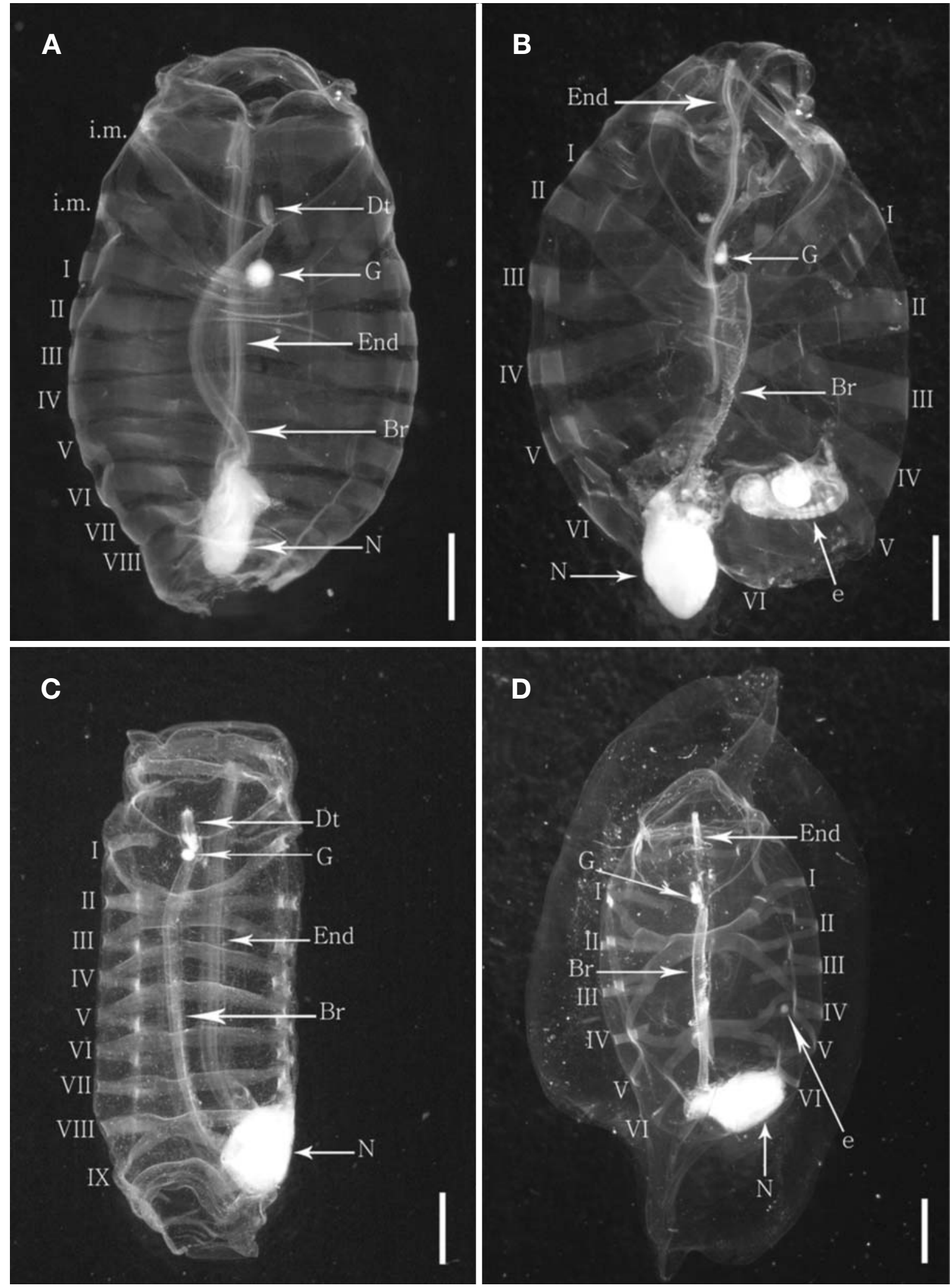

Fig. 1. Ihlea punctata. A, solitary zooid, dorsal view; B, aggregate zooid, dorsal view. Salpa fusiformis. C, solitary zooid, dorsal view; $\mathrm{D}$, aggregate zooid, dorsal view ( $\mathrm{Br}$, branchial septum; $\mathrm{Dt}$, dorsal tubercle; e, embryo; End, endostyle; G, ganglion; i.m., intermediate muscle; N, nucleus; I-VX, body muscles). Scale bars $=3 \mathrm{~mm}(\mathrm{~A}, \mathrm{~B}, \mathrm{D}), 2 \mathrm{~mm}(\mathrm{C})$. 
MIII to MVI contiguous or fused in mid-dorsal region. Dorsal tubercle and ganglion anteriodorsally. Branchial septum slender, extending from ganglion to beginning of gut. Endostyle thin, extending from behind oral to posterior ventrally. Gut project with tight circular loop. Embryo between MV and MVI in right side.

Remarks. Mature specimens of solitary zooid showed the stolon tightly coiled underneath the gut nucleus. All examined specimens are sinistral individuals.

Distribution. Pacific Ocean, Atlantic Ocean, Mediterranean Sea.

Genus Salpa Forskal, 1775

Salpa fusiformis Cuvier, 1804 (Fig. 1C, D)

Salpa fusiformis Cuvier, 1804, p. 112, fig. IV (cited from Berrill, 1950; Yount, 1954); Tokioka, 1937, p. 223; Fraser, 1947 , p. 2; Thompson, 1948, p. 156, pl. 70, figs. 1, 2, pl. 71, figs. 1-3; Berrill, 1950, p. 293, fig. 106; Yount, 1954, p. 297, figs. 11,12 , 15, 16; Berrill, 1961, p. 150; Rho, 1967, p. 369, fig. 4; Gosner, 1971, p. 611, fig. 24. Yamaji, 1984, p. 447, pl. 139, figs. 2a, 2b; Zheng et al., 1989, p. 389; Madin, 1991, p. 111, fig. T-14; Chihara and Murano, 1997, p. 1366; Van Soest, 1998, p. 237, fig. 14.2, table 14.2; Esnal and Daponte, 1999, p. 1431, fig. 3.10.

Material examined. 1 solitary zooid and 2 aggregate zooids, East Sea, $38^{\circ} 00^{\prime} \mathrm{N} 130^{\circ} 33^{\prime} \mathrm{E}, 18$ Apr. 2001; 358 solitary zooids and 2143 aggregate zooids, South Sea, $35^{\circ} 39^{\prime} \mathrm{N} 130^{\circ}$ 29'E, 24 Apr. 2001; 100 solitary zooids and 14 aggregate zooids, South Sea, $35^{\circ} 14^{\prime} \mathrm{N} 129^{\circ} 47^{\prime} \mathrm{E}, 24$ Apr. 2001; 12 aggregate zooids, Straits of Korea, $32^{\circ} 29^{\prime} \mathrm{N} 127^{\circ} 29^{\prime} \mathrm{E}, 24$ Sep. 2002; 1 solitary zooid and 1 aggregate zooid, East Sea, $37^{\circ} 30^{\prime} \mathrm{N} 129^{\circ} 10^{\prime} \mathrm{E}, 1$ Dec. 2003; 6 solitary zooids, South Sea, $34^{\circ} 05^{\prime} \mathrm{N} 127^{\circ} 96^{\prime} \mathrm{E}, 1$ Apr. 2007; 2 aggregate zooids, South Sea, $34^{\circ} 05^{\prime} \mathrm{N} 127^{\circ} 96^{\prime} \mathrm{E}$, 4 Jan. 2008 ; 8 solitary zooids and 48 aggregate zooids, South Sea, $34^{\circ} 05^{\prime} \mathrm{N} 127^{\circ} 96^{\prime} \mathrm{E}, 1$ Apr. 2008; 2 solitary zooids and 7 aggregate zooids, South Sea, $34^{\circ} 05^{\prime} \mathrm{N} 127^{\circ} 96^{\prime} \mathrm{E}, 3$ Apr. 2008; 2 aggregate zooids, Jejudo Is., $33^{\circ} 12^{\prime} \mathrm{N} 126^{\circ} 36^{\prime} \mathrm{E}, 22$ June 2009.

Description. Solitary zooid (Fig. 1C): 5-35 mm long, elongate, cylindrical body. Test entirely smooth. Oral and atrial opening terminal. Nine muscles continuous dorsally, while interrupted ventrally. MI to MIII and MVIII to MIX widely fused in mid-dorsal line. MIV to MVII arranged parallel. Dorsal tubercle elongated with ends turned inwards. Endostyle thin, extends from behind oral to front of gut. Branchial septum slender, extend from ganglion to gut. Gut forms a compact nucleus between MVIII and MIX ventrally.

Aggregate zooid (Fig. 1D): 5-38 mm long, Elongate, fusiform body with anterior and posterior projections. Test thick, film, entirely smooth. Six body muscles continuous dorsally, while interrupted ventrally. MI to MIV and MV to MVI contiguous or fused in mid-dorsal line. MV to MVI fused laterally. Dorsal tubercle short and straight. Endostyle thin, extends from behind oral to beginning of gut. Branchial septum slender, extending from ganglion to gut. Gut with tight circular loop, located posterior in right side. Embryo locates behind of MV in right side dorsally.

Remarks. Mature specimens of solitary zooid showed the stolon extending forward from nucleus. Rho (1967) described only aggregate zooid in Korea. In this study, description of solitary zooids and taxonomic characters of aggregate zooids undescribed in Rho (1967) are added.

Distribution. Pacific Ocean, Atlantic Ocean, Indian Ocean, Antarctic Ocean, Arctic Ocean.

\section{REFERENCES}

Berrill, N.J., 1950. The Tunicata, with an Account of the British Species. Ray Soc., Publ., Lond., pp. 1-354.

Berrill, N.J., 1961. With the vast spaces of most of the oceans of a habitat this delicate creature has developed a curious life cycle that stretches the reproductive processes to their limits. Sci. Amer., 1: 150-158.

Chihara, M. and M. Murano, 1997. An Illustrated Guide to Marine Plankton in Japan. Tokai Univ. Press, Tokyo, pp. 11574.

Esnal, G.B. and M.C. Daponte, 1999. Salpida. In: South Atlantic Zooplankton (Ed., D. Boltovskoy). pp. 1409-1421. Backhuys Publ., Leiden.

Fraser, J.H., 1947. Thaliacea, I. Family: Salpidae. Zooplankton sheet, CIEM, 9: 1-4.

Gosner, K.L., 1971. Guide to Identification of Marine and Estuarine Invertebrates. John Wiley and Sons Publ. Co., New York, pp. 1-693.

Kim, S., J.H. Won and C.-B. Kim, 2010. A new record of Iasis zonaria (Salpida: Salpidae) in Korean waters. Korean J. Syst. Zool., 26(2): 161-163.

Madin, L.P., 1991. Distribution and taxonomy of zooplankton in the Alboran Sea and adjacent western Mediterranean: a literature survey and field guide. Woods Hole Oceanogr. Inst., pp. 1-147.

Rho, B.J., 1967. Taxonomic studies on the Tunicata. Korea Culture Research Institute Publ., 10: 361-371.

Thompson, H., 1948. Pelagic tunicates of Australia. Commonwealth Council for Scientific and Industrial Research Australia, Melbourne, pp. 1-196.

Tokioka, T., 1937. Notes on salps and doliolums occurring on the Pacific coast of middle Japan. Annot. Zool. Japan, 16: 219-235.

Van Soest, R.W.M., 1975. Observation on taxonomy and distribution of some salpa (Tunicata, Thaliacea), with descriptions of three new species. Beaufortia, 23: 105-129.

Van Soest, R.W.M., 1998. The cladistic biogeography of salps 
and pyrosomas. In: The Biology of Pelagic Tunicates (Ed., Q. Bone). pp. 232-249. Oxford University Press, Oxford. Yamaji, I., 1984. Illustrations of the Marine Plankton of Japan. Hoikusha Publ. Co. ltd., pp. 1-537.

Yount, J.L., 1954. The taxonomy of the Salpidae (Tunicata) of the central Pacific Ocean. Pac. Sci., 8: 276-330.

Zheng, Z., S. Li, Q. Zhou, Z. Xu and Q. Yang, 1989. Marine Planktology. China Ocean Press, pp. 1-454.

Received October 14, 2010 Accepted November 12, 2010 